\title{
Prevalence of antibodies against measles, mumps, and rubella before and after vaccination of school-age children with three different triple combined viral vaccines, Rio Grande do Sul, Brazil, 1996
}

\author{
Boaventura Antônio dos Santos, ${ }^{1}$ Selir M. Stralioto, ${ }^{2}$ Marilda M. Siqueira, ${ }^{3}$ \\ Tani S. Ranieri, ${ }^{4}$ Marilina Bercini, ${ }^{4}$ Maria Tereza Schermann, ${ }^{4}$ \\ Mário Bernardes Wagner, ${ }^{1}$ and Themis R. Silveira ${ }^{1}$
}

Suggested citation

dos Santos BA, Stralioto SM, Siqueira MM, Ranieri TS, Bercini M, Schermann MT, Wagner MB, Silveira TR. Prevalence of antibodies against measles, mumps, and rubella before and after vaccination of school-age children with three different triple combined viral vaccines, Rio Grande do Sul, Brazil, 1996. Rev Panam Salud Publica. 2006; 20(5):299-306.

ABSTRACT Objective. We evaluated the seroprevalence for measles, mumps, and rubella in school-age children (6-12 years old) before and after the administration of three triple combined viral vaccines. Methods. In two municipal schools of Rio Grande do Sul, Brazil, 692 blood samples were collected before vaccination and 636 samples 21 to 30 days after vaccination during 1996. IgG antibody seropositivity was investigated by enzyme-linked immunosorbent assay (measles and mumps with Enzygnost [Behring, Marburg, Germany]; rubella with Rubenostika [Organon Teknica, Boxtel, the Netherlands]). The vaccines compared were: A: E-Zagreb, L-Zagreb, and Wistar RA 27/3 (Tresivac); B: Moraten, J-Lynn, and Wistar RA 27/3 (M-M-R II); and C: Schwarz, Urabe AM-9, and Wistar RA 27/3 (Trimovax).

Results. Before vaccination, $79.2 \%$ [95\% confidence interval $(\mathrm{CI})=76.0 \%-82.2 \%$ ] of the samples were positive for measles, $69.4 \%$ (95\% CI $=65.8 \%-72.8 \%)$ for mumps, and $55.4 \%$ $(95 \% C I=51.6 \%-59.2 \%)$ for rubella. After vaccination with the $A, B$, and $C$ vaccines, seropositivity was $100.0 \%, 99.5 \%$, and $100.0 \%$, respectively for measles; $99.5 \%, 94.5 \%$, and $92.0 \%$ for mumps; and $92.6 \%, 91.3 \%$, and $88.6 \%$ for rubella.

Conclusions. About one-fifth (20.8\%) of the schoolchildren who could have been vaccinated against measles at age 9 months had levels of antibodies insufficient for protection. In the sample of schoolchildren without previous vaccination against mumps and rubella, high proportions of susceptible levels were found. All vaccines were immunogenic, but vaccine A yielded a seroconversion rate of $99.5 \%$ for the mumps component, which was significantly higher than the other two vaccines $(\mathrm{P}<0.01)$.

Key words Vaccination; measles-mumps-rubella vaccine; antibodies, viral; Brazil.

Faculdade de Medicina da Universidade Federal do Rio Grande do Sul, Porto Alegre, Rio Grande do Sul, Brasil. Send correspondence and reprint requests to: Boaventura Antônio dos Santos, Núcleo de Pesquisa em Vacinas, Hospital de Clínicas de Porto Alegre, rua Ramiro Barcelos, $\mathrm{n}^{\circ} 2350$, CEP 90035-003, Porto Alegre, Rio Grande do Sul, Brasil; telephone: 55 (51) 2101-8749 or 55 (51) 2101-8748; e-mail: nuclivac@hcpa.ufrgs.br
2 Laboratório Central de Saúde Pública (LACEN), Setor de Virologia, Secretaria Estadual de Saúde do Rio Grande do Sul (SES/RS), Porto Alegre, Rio Grande do Sul, Brasil.

3 Fundação Oswaldo Cruz, Instituto Oswaldo Cruz Departamento de Virologia, Laboratório de Vírus Respiratórios e Sarampo, Rio de Janeiro, Rio de Janeiro, Brasil.

\footnotetext{
Secretaria Estadual de Saúde do Rio Grande do Sul, Centro Estadual de Vigilância e Saúde, Divisão de Vigilância Epidemiológica, Porto Alegre, Rio Grande do Sul, Brasil.
} 
The use of safe and effective vaccines has been a consolidated practice in public health since the 1970s, and has had a great impact on the incidence of infectious diseases. Furthermore, it is the public health practice that has been credited with the greatest cost-effectiveness. Since 1974 the World Health Organization (WHO), through the Expanded Program on Immunization, has carried out extensive global vaccination programs. Despite this, almost two million children still die each year from diseases that could be avoided by effective, safe, and low-cost vaccines $(1,2)$.

Measles is the main example of this situation: Although an effective, lowcost vaccine is available, there are 40 million cases and 875000 deaths per year, mainly in developing countries, with about half of these cases occurring in Africa $(3,4)$. This situation is due to inadequate attention to vaccination in the promotion of health, as seen by the low vaccination coverage in these regions. In the Region of the Americas, the Pan American Health Organization (PAHO) has implemented vaccination programs for the eradication of measles since 1994, following the example of the successful eradication of polio in the Region. The basic strategies have been catch-up (mass vaccination), keep-up (routine vaccination), and follow-up (follow-up vaccination), along with the establishment of an effective surveillance system. These strategies resulted in substantial progress in the Region, where indigenous measles is no longer endemic. However, the data for epidemiologic and molecular surveillance indicate that countries in the Americas are continually exposed to the measles virus from other regions of the world (5-7). The WHO Strategic Plan for 20012005 to reduce mortality and eliminate measles proposed the adoption of measures to reduce by $50 \%$ the annual number of deaths due to measles by 2005 in comparison to 1999 levels (875000 deaths), and to achieve and maintain the interruption of indigenous transmission of the virus in large geographical areas (8). The utilization of combined vaccines against measles, mumps, and rubella (MMR) in these vaccination programs will, it is hoped, also eliminate mumps and congenital rubella.

Mumps continues to be endemic in various regions of the world, and the number of outbreaks has recently increased $(9,10)$. Controlling and eliminating rubella is important in public health because of the teratogenic effects that may occur when the infection is acquired during the first months of gestation. Wide circulation of the rubella virus has been documented in various countries of the world, and therefore the prevention of congenital rubella syndrome today constitutes a great challenge in public health $(11,12)$.

Studies of the prevalence of antibodies against measles, mumps, and rubella in a given population are of interest as a way to objectively measure the proportion of the population that has been immunized. These data can also be used to support specific strategies and allocate resources toward the control of these three diseases, especially for the eradication of measles. Furthermore, the existence of well-tolerated and effective MMR (triple viral) vaccines constitutes a fundamental prerequisite for any extensive immunization program in infancy and childhood. It was for these reasons that we carried out this study, which was supported by the Ministry of Health of Brazil.

\section{MATERIALS AND METHODS}

\section{Study design}

This study was a double-blind, randomized clinical trial divided into two parts: The first evaluated the potential adverse reactions to three different vaccines, and the results were published previously (13). The second part, reported here, evaluated seroprevalence before and after the administration of three different triple viral vaccines in schoolchildren between the ages of 6 and 12 years living in Porto Alegre and Santa Maria (Rio Grande do Sul, Brazil). The project involved the Federal University of Rio Grande do Sul, the Federal University of Santa Maria, the State Health and Education Departments of Rio Grande do Sul, and the Municipal Department of Health and Education of Porto Alegre and Santa Maria.

Five schools (both public and private) from Porto Alegre and three from Santa Maria were randomly selected to participate in the seroprevalence study. Vaccinations took place during 26 to 30 August 1996 and 9 to 12 September 1996.

Children were excluded from the study if they presented any of the following contraindications for the triple viral vaccine: presence of congenital or acquired immunodeficiency; presence of malignant neoplasia; treatment with high doses of corticosteroids (equivalent to prednisone at a dose of $2 \mathrm{mg} /$ $\mathrm{kg}$ /day for children during one week or more) or with other immunodepressive therapies such as antineoplastic chemotherapy, radiotherapy, etc.; previous history of anaphylactic reaction to neomycin or chicken egg, understood as the appearance of urticaria, difficulty breathing, glottis edema, hypotension or shock up to $1 \mathrm{~h}$ after exposure to the allergen; pregnancy; use of normal human immunoglobulin, complete blood, or plasma infusion in the previous 3 months; or moderate to severe acute febrile condition at the time of enrollment.

\section{Vaccines used}

Table 1 shows the manufacturers and composition of each of the three MMR vaccines compared here, designated $A, B$, and $C$. The volume of each dose for all three vaccines was $0.5 \mathrm{~mL}$, and the vaccine was administrated subcutaneously in the deltoid muscle of the arm. Before the vaccine was administered, a total of 692 blood samples (S1) were obtained, and 636 samples (S2) were collected 21 to 30 days after vaccination.

\section{Laboratory methods}

Serum samples S1 and S2 were delivered to the Virology Division of the Laboratório Central do Rio Grande do Sul (LACEN/RS), where they were split 
TABLE 1. Vaccines used in the immunogenicity study of three combined triple viral vaccines, Rio Grande do Sul, Brazil, $1996^{\mathrm{a}}$

\begin{tabular}{|c|c|c|c|c|c|}
\hline Vaccine code & Vaccine & Manufacturer & Strains & Doses & Other components \\
\hline \multirow[t]{3}{*}{ A } & \multirow[t]{3}{*}{ Tresivac } & \multirow[t]{3}{*}{ Serum Institute of India } & Edmonston-Zagreb & $1000 \mathrm{TCID}_{50}^{\mathrm{b}}$ & \multirow[t]{3}{*}{ Not listed by the manufacturer } \\
\hline & & & Leningrad-Zagreb & $5000 \mathrm{TCID}_{50}$ & \\
\hline & & & Wistar RA 27/3 & $1000 \mathrm{TCID}_{50}$ & \\
\hline \multirow[t]{3}{*}{ B } & \multirow[t]{3}{*}{ M-M-R II } & \multirow[t]{3}{*}{ Merck-Sharp \& Dohme } & Moraten & $1000 \mathrm{TCID}_{50}$ & \multirow{3}{*}{$\begin{array}{l}\text { Traces of neomycin, sorbitol, } \\
\text { and hydrolized gelatin }\end{array}$} \\
\hline & & & Jeryl Lynn & $5000 \mathrm{TCID}_{50}$ & \\
\hline & & & Wistar RA 27/3 & $1000 \mathrm{TCID}_{50}$ & \\
\hline \multirow[t]{3}{*}{ C } & \multirow[t]{3}{*}{ Trimovax } & \multirow[t]{3}{*}{ Institut Pasteur Mérieux } & Schwarz & $1000 \mathrm{TCID}_{50}$ & \multirow{3}{*}{$\begin{array}{l}\text { Neomycin, hydrolized gelatin, } \\
\text { and traces of phenol red }\end{array}$} \\
\hline & & & Urabe AM-9 & $5000 \mathrm{TCID}_{50}$ & \\
\hline & & & Wistar RA 27/3 & $1000 \mathrm{TCID}_{50}$ & \\
\hline
\end{tabular}

a Source: dos Santos et al. (13).

${ }^{\mathrm{b}} \mathrm{TCID}_{50}=$ Dose able to infect $50 \%$ of the tissue culture.

into halves and stored in vials at $-20{ }^{\circ} \mathrm{C}$ and $-80{ }^{\circ} \mathrm{C}$. IgG antibodies for measles, rubella, and mumps were studied with commercial enzyme-linked immunosorbent assay (ELISA) kits. Enzygnost (Behring, Marburg, Germany) was used for measles and mumps, and Rubenostika (Organon Teknica, Boxtel, the Netherlands) for rubella. Samples collected at S1 and S2 with negative or borderline results for measles and mumps (stored at $-80{ }^{\circ} \mathrm{C}$ ) were later tested with the plaque reduction neutralization test, and samples with negative or borderline results for the rubella were also checked with the hemagglutination inhibition technique. Tests with these two techniques were carried out at the Immunobiological Technology Institute of the Fundação Oswaldo Cruz. All assays were done according to the manufacturer's instructions.

\section{Ethical considerations}

The protocol for this research was approved by the Scientific and Research Ethics Committee of the Hospital de Clínicas de Porto Alegre and of the Federal University of Santa Maria. The parents or other persons responsible for the children received information and clarification about the vaccines used and possible risks of adverse reactions, and each parent or guardian signed a terms of consent form to allow their child to participate in the study.

\section{Statistical analysis}

Quantitative data are reported as the average (mean) and standard deviation, and were compared by analysis of variance (ANOVA); significance of the differences was determined with the Tukey test. Categorical data are reported as frequencies and percentages, and were compared with the chisquare test. Subgroups according to age and gender were compared with the chi-square test for linear trend. Confidence intervals were calculated at $95 \%$, based on a binomial distribution. The data were processed and analyzed with the help of SPSS v. 12 software for Windows, and PEPI (Programs for Epidemiologists) v. 4.0.

\section{RESULTS}

\section{Seroprevalence before vaccine administration}

A total of 692 blood samples were obtained from the students aged 6 to
12 years and tested for the prevalence of antibodies against measles, mumps, and rubella before administration of the triple viral vaccine.

Antibodies for the measles. Of all samples, $79.2 \%$ [95\% confidence interval $(\mathrm{CI})=76.0 \%-82.2 \%$ ], $7.8 \%$, and $13.0 \%$, respectively, were positive, borderline, and negative for antibodies against measles (Table 2). No significant association between seropositivity and gender $(P=0.60)$ was found. When schoolchildren were stratified by age, no linear trend was observed in the proportions of positivity, thus there was no evidence of increasing prevalence with increasing age $(P=0.08)$. No evidence of a linear trend in the proportions of seropositivity was found for measles when the sample was stratified according to gender and age $(P=0.37$ for boys, $P=0.08$ for girls).

Antibodies for mumps. A total of $69.4 \%$ $(95 \% \mathrm{CI}=65.8 \%-72.8 \%), 3.5 \%$, and $27.2 \%$ of the samples were positive, borderline, and negative, respectively, for antibodies against mumps (Table 3). No significant association between seropositivity and gender $(P=0.80)$ 
TABLE 2. Prevalence of antibodies against measles, stratified by age, before vaccination in students in Porto Alegre and Santa Maria, Rio Grande do Sul, Brazil, 1996a

\begin{tabular}{|c|c|c|c|c|c|c|c|c|c|}
\hline \multirow{2}{*}{$\begin{array}{c}\text { Age } \\
\text { (years) }\end{array}$} & \multirow[b]{2}{*}{ No. } & \multicolumn{2}{|c|}{ Negative } & \multicolumn{2}{|c|}{ Borderline } & \multicolumn{3}{|c|}{ Positive } & \multirow{2}{*}{$\begin{array}{c}\text { Linear } \\
\text { tendency } \\
P\end{array}$} \\
\hline & & $n$ & $\%$ & $n$ & $\%$ & $n$ & $\%$ & $95 \% \mathrm{Cl}$ & \\
\hline 7 & 164 & 20 & 12.2 & 12 & 7.3 & 132 & 80.5 & $73.6-86.3$ & \\
\hline 8 & 142 & 8 & 5.6 & 10 & 7.0 & 124 & 87.3 & $80.7-92.3$ & \\
\hline 9 & 126 & 20 & 15.9 & 5 & 4.0 & 101 & 80.2 & $72.1-86.7$ & \\
\hline 10 & 150 & 29 & 19.3 & 21 & 14.0 & 100 & 66.7 & $58.5-74.1$ & \\
\hline $11-12$ & 110 & 13 & 11.8 & 6 & 5.5 & 91 & 82.7 & $74.3-89.3$ & \\
\hline Total/Overall & 692 & 90 & 13.0 & 54 & 7.8 & 548 & 79.2 & $76.0-82.2$ & 0.08 \\
\hline
\end{tabular}

a Data are presented as the number and percentages, with $95 \%$ confidence intervals $(95 \% \mathrm{Cl})$ for positive levels based on a binomial distribution.

TABLE 3. Prevalence of antibodies against mumps, stratified by age, before vaccination in students in Porto Alegre and Santa Maria, Rio Grande do Sul, Brazil, 1996a

\begin{tabular}{|c|c|c|c|c|c|c|c|c|c|}
\hline \multirow{2}{*}{$\begin{array}{c}\text { Age } \\
\text { (years) }\end{array}$} & \multirow[b]{2}{*}{ No. } & \multicolumn{2}{|c|}{ Negative } & \multicolumn{2}{|c|}{ Borderline } & \multicolumn{3}{|c|}{ Positive } & \multirow{2}{*}{$\begin{array}{c}\text { Linear } \\
\text { tendency } \\
P\end{array}$} \\
\hline & & $n$ & $\%$ & $n$ & $\%$ & $n$ & $\%$ & $95 \% \mathrm{Cl}$ & \\
\hline 7 & 164 & 52 & 31.7 & 8 & 4.9 & 104 & 63.4 & $55.5-70.8$ & \\
\hline 8 & 142 & 43 & 30.3 & 3 & 2.1 & 96 & 67.6 & $59.2-75.2$ & \\
\hline 9 & 126 & 36 & 28.6 & 5 & 4.0 & 85 & 67.5 & $58.5-75.5$ & \\
\hline 10 & 150 & 31 & 20.7 & 6 & 4.0 & 113 & 75.3 & $67.6-82.0$ & \\
\hline $11-12$ & 110 & 26 & 23.6 & 2 & 1.8 & 82 & 74.5 & $65.4-82.4$ & \\
\hline Total/Overall & 692 & 188 & 27.2 & 24 & 3.5 & 480 & 69.4 & $65.8-72.8$ & 0.01 \\
\hline
\end{tabular}

a Data are presented as the number and percentages, with $95 \%$ confidence intervals $(95 \% \mathrm{Cl})$ for positive levels based on a binomial distribution.

was found. When the sample was stratified by age, a positive linear tendency $(P=0.01)$ was observed, which demonstrated an increase in the proportion of seropositivity of $3.1 \%$ for each year increase in age. However, when the sample was stratified by gender and age, the analysis showed a significant difference between boys $(P<0.01)$ and girls $(P=0.46)$. This demonstrated that in boys, prevalence showed a growth effect in the proportion of seropositivity of $5.1 \%$ per year increase in age, whereas in girls there was no evidence of an annual increase in the proportion of seropositivity.

Antibodies for rubella. A total of 55.4\% $(95 \% \mathrm{CI}=51.6 \%-59.2 \%), 0.6 \%$, and $44.0 \%$ of the samples were positive, borderline, and negative, respectively, for antibodies against rubella (Table 4).
No significant association between seropositivity and gender $(P=0.96)$ was found. When the sample was stratified by age, a positive linear tendency $(P=0.01)$ was observed, which demonstrated a growth of $3.8 \%$ per year increase in age. However, when the sample was stratified by gender and age, we found a significant difference between boys $(P=0.17)$ and girls $(P=0.01)$. The latter subgroup showed a positive growth effect of $4.9 \%$ per year increase in age, whereas among boys there was no evidence of a linear increase in seropositivity.

\section{Seroprevalence after vaccine administration}

Postvaccination blood samples were obtained for a total of 636 children. This sample (S2) was smaller than the prevaccination sample (S1) because 56 children were absent from the school on the day the second blood sample was collected. Table 5 compares the three vaccines according to age, gender, and proportions of seroconversion. The analysis showed that there was no statistical significance between age subgroups $(P=0.66)$ or gender $(P=0.43)$.

Twenty-one to 30 days after vaccination, antibody seroprevalence against measles showed seropositivity rates of $100.0 \%$ with vaccine $\mathrm{A}, 99.5 \%$ with vaccine $B$, and $100.0 \%$ with vaccine $C$. There were no statistically significant differences between the three vaccines $(P=0.39)$.

After vaccination, antibody seroprevalence against mumps showed seropositivity rates of $99.5 \%$ with vaccine A, 94.5\% with vaccine B, and $92.0 \%$ with vaccine $C$. The rate of seropositivity was significantly higher with vaccine $A$ than with vaccine $B$ or $C(P<0.01$ for both comparisons). The latter two vaccines did not differ significantly in seropositivity $(P>0.05)$.

Seropositivity rates against rubella after vaccination were $92.6 \%$ with vaccine A, 91.3\% with vaccine $B$, and $88.6 \%$ with vaccine $C$. There were no statistically significant differences between the three vaccines $(P=0.35)$.

\section{DISCUSSION}

All sera were analyzed with the ELISA technique, an accurate test that correlates well with protection, and that is used in epidemiological studies (14). Borderline and negative results were retested for greater precision with the plaque reduction neutralization test for measles and mumps, and the hemagglutination inhibition test for rubella.

\section{Seroprevalence before vaccine administration}

The school-age children (6-12 years old) who participated in this study had at least two opportunities to receive the measles vaccine: as a routine 
TABLE 4. Prevalence of antibodies against rubella, stratified by age, before vaccination in students in Porto Alegre and Santa Maria, Rio Grande do Sul, Brazil, 1996a

\begin{tabular}{|c|c|c|c|c|c|c|c|c|c|}
\hline \multirow{2}{*}{$\begin{array}{c}\text { Age } \\
\text { (years) }\end{array}$} & \multirow[b]{2}{*}{ No. } & \multicolumn{2}{|c|}{ Negative } & \multicolumn{2}{|c|}{ Borderline } & \multicolumn{3}{|c|}{ Positive } & \multirow{2}{*}{$\begin{array}{c}\text { Linear } \\
\text { tendency } \\
P\end{array}$} \\
\hline & & $n$ & $\%$ & $n$ & $\%$ & $n$ & $\%$ & $95 \% \mathrm{Cl}$ & \\
\hline 7 & 164 & 83 & 50.6 & 0 & 0.0 & 81 & 49.4 & $41.5-57.3$ & \\
\hline 8 & 142 & 68 & 47.9 & 1 & 0.7 & 73 & 51.4 & $42.9-59.9$ & \\
\hline 9 & 126 & 55 & 43.7 & 1 & 0.8 & 70 & 55.6 & $46.4-64.4$ & \\
\hline 10 & 149 & 61 & 40.9 & 1 & 0.7 & 87 & 58.4 & $50.0-66.4$ & \\
\hline $11-12$ & 110 & 37 & 33.6 & 1 & 0.9 & 72 & 65.5 & $55.8-74.3$ & \\
\hline Total/Overall & 691 & 304 & 44.0 & 4 & 0.6 & 383 & 55.4 & $51.6-59.2$ & $<0.01$ \\
\hline
\end{tabular}

a Data are presented as the number and percentages, with $95 \%$ confidence intervals $(95 \% \mathrm{Cl})$ for positive levels based on a binomial distribution.

vaccination at 9 months of age, and during the mass vaccination campaign of 1992. Vaccination coverage in Rio Grande do Sul from 1984 to 1990 (the period when the schoolchildren in this study were born) varied from $65.6 \%$ to $85.5 \%$, and in the 1992 mass vaccination campaign coverage reached 100\%.

The results of the present study showed a $13.0 \%$ rate of seronegative findings and a $7.8 \%$ rate for borderline results (Table 2). The WHO considers that the following proportions of susceptibility need to be achieved to interrupt the transmission of measles: $<15 \%$ at $1-4$ years, $<10 \%$ at $5-9$ years, and $<5 \%$ at age $>10$ years (15). The proportions of seronegative findings in our sample of schoolchildren were well above those considered safe by WHO for interrupting the transmission of measles.

A seroepidemiological study carried out in Brazil (São Paulo) by Cox et al. (16) found low concentrations of unprotective antibodies in children who had previously been vaccinated for measles. This study also considers that in this population, a proportion of individuals (with previous vaccination) had insufficient levels of antibodies for protection. Similar results were observed by Cutts et al. (17) in a study of antibody prevalence among children under the age of 15 years in Bolivia, with a rate of vaccine coverage of $77 \%$. These authors found low levels of antibodies in a high proportion $(30 \%-40 \%)$ of the population. These results, however, may be related to three main fac- tors: low coverage of routine vaccination, primary and secondary vaccine failures, and vaccine effectiveness. Primary vaccine failure is the lack of an immune response after administration of the vaccine, and secondary vaccine failure is a drop in antibody levels over time to very low or undetectable (i.e., unprotective) levels $(18,19)$.

Students between the ages of 6 and 12 years who participated in our study had not previously received mumps or rubella vaccination. They had been exposed to the indigenous virus, and therefore the antibody positivity rates we detected were due to naturally acquired infections, and reflected the circulation of the virus during this period. For mumps, we found an overall rate of seropositivity of $69.4 \%$ (95\% $\mathrm{CI}=65.8 \%-72.8 \%$ ) (Table 3 ). No significant association was found between seropositivity and gender $(P=0.96)$, which is in agreement with earlier findings (20). However, stratification of the results by age and gender showed that in boys, the proportion of positivity increased by $5.1 \%$ per year increase in age-an effect not observed in girls. We found no earlier studies in the Region of the Americas that correlated seroprevalence rates with age or gender.

For rubella, the overall rate of seropositivity was $55.4 \%$ (95\% CI = $51.6 \%-59.2 \%$ ) (Table 4 ). A seroepidemiological study by Souza et al. (21) involved 1400 sera from a nonimmunized population of children in São Paulo between 2 and 14 years of age, and 329 sera from umbilical cord blood, and yielded the following results: at 6 years of age, $55.9 \%$ of the sera were positive; at 8 years, $57.6 \%$ were positive; at 10 years, $76.2 \%$ were positive; and at 14 years, $80.2 \%$ of the sera were positive. A 95\% seropositivity rate was found in the umbilical cord blood of mothers between the ages of 20 and 29 years. The authors concluded that a large number of women were infected during their reproductive years, and that this population constituted an important public health problem. The Projeto Pesquisa de Anticorpos na Rubéola, Fundação Nacional da Saúde, Instituto Evandro Chagas (22) evaluated the prevalence in women in five states in Brazil. In the 7111 sera collected for this study, seropositivity in girls between 10 and 12 years of age was $59.9 \%$. The results of this study are similar to ours, considering the age range studied.

We initially found no significant association between seropositivity for rubella and gender $(P=0.96)$. However, when the sample was stratified by gender and age, we found a significant difference between boys $(P=$ $0.17)$ and girls $(P=0.01)$, with girls showing a positive growth effect of $4.9 \%$ per year increase in age, whereas among boys there was no evidence of any growth effect. Morgan-Capner et al. (23), in their study of antibodies for measles, mumps, and rubella in England, found that the proportion of subjects who did not have rubella antibodies was significantly lower in girls and women than in boys and men between the ages of 10 and 30 years $(P<$ $0.01)$. The authors related this finding to the selective effect of vaccination for rubella in girls and women. Studies in Canada by Mitchell et al. $(24,25)$ suggested the existence of hormonal and genetic influences in specific immunity to the rubella virus. This raised the possibility of differential responses to infection, which might explain why women are more predisposed to the adverse results of rubella infection and immunization. It should be noted that in our previous study, which evaluated the reactogenicity of the vaccines, joint manifestations (e.g., arthralgia) possibly linked to the rubella compo- 
TABLE 5. Comparisons by age and gender of the proportions of seroconversion before and after the administration of the triple combined viral vaccines in schoolchildren in Porto Alegre and Santa Maria, Rio Grande do Sul, Brazil, 1996

\begin{tabular}{|c|c|c|c|c|}
\hline & $\begin{array}{l}\text { A, Tresivac } \\
\text { (SII) } \\
\end{array}$ & $\begin{array}{c}\text { B, M-M-R II } \\
(\mathrm{MSD}) \\
\end{array}$ & $\begin{array}{l}\text { C, Trimovax } \\
\text { (IPM) }\end{array}$ & \\
\hline & No. $=216$ & No. $=219$ & No. $=201$ & $P$ \\
\hline Age (years) & $8.93 \pm 1.42$ & $8.92 \pm 1.41$ & $8.82 \pm 1.38$ & $0.66^{b}$ \\
\hline Gender (M:F) & $52: 48$ & $46: 54$ & $46: 54$ & $0.43^{c}$ \\
\hline \multicolumn{5}{|l|}{ Seropositivity rate } \\
\hline \multicolumn{5}{|l|}{ Measles } \\
\hline Before (S1) & $175(81.0)$ & $171(78.1)$ & $158(78.6)$ & $0.73^{c}$ \\
\hline After (S2) & $216(100.0)$ & 218 (99.5) & $201(100)$ & $0.39^{c}$ \\
\hline \multicolumn{5}{|l|}{ Mumps } \\
\hline Before (S1) & $149(69.0)$ & $161(73.5)$ & $133(66.2)$ & $0.25^{c}$ \\
\hline After (S2) & 215 (99.5) & $207(94.5)^{d}$ & $185(92.0)^{d}$ & $<0.01^{c}$ \\
\hline \multicolumn{5}{|l|}{ Rubella } \\
\hline Before (S1) & $129(59.7)$ & 118 (53.9) & $107(53.2)$ & $0.33^{c}$ \\
\hline After (S2) & 201 (92.6) & 200 (91.3) & $179(88.6)$ & $0.35^{c}$ \\
\hline
\end{tabular}

a Data are presented as the mean \pm standard deviation, odds of masculine or feminine gender, and number (percentage). SII: Serum Institute of India, IPM: Institut Pasteur-Mérieux, MSD: Merck-Sharp \& Dohme.

b ANOVA.

${ }^{c}$ Chi-square test.

d Significantly lower than the Tresivac group.

nent of the vaccines occurred mostly in girls (65\% of the cases) (13). Additional studies are necessary to better evaluate the interactions between gender and infection by the rubella virus.

\section{Seroprevalence after vaccine administration}

This study also analyzed the prevalence of antibodies for each of the components of the three vaccines 21 to 30 days after administration. All three vaccines showed good seroconversion rates for measles, mumps, and rubella (Table 5). The results are similar to other studies documenting that mass vaccination can be a useful strategy for the control of these diseases. Panutti et al. (26) observed a significant difference in the prevalence of antibodies in a São Paulo population when they compared those vaccinated in the 1987 mass vaccination campaign (98\%) with those who were not vaccinated $(91.3 \%)$. Bartolini et al. (27) and Massad et al. (28) also obtained similar results.

Evaluation of the protective capacity of the different triple viral vaccines is important mainly to inform the selection of the viral strains that make up the vaccines. Although these vaccines use tential adverse reactions of the three vaccines studied here (13), vaccine A (with the L-Zagreb strain for measles) showed greater reactogenicity, manifested mainly as greater parotid gland swelling, with a relative risk of 5.72 compared to vaccine B (Jeryl-Lynn strain) and a relative risk of 2.33 compared to vaccine C (Urabe strain) (13).

One limitation of this study is the time interval between data collection and analysis. However, ours are the only data available for the prevalence of these diseases in the region during the period that preceded introduction of the triple viral vaccine in the vaccination calendar in our setting, before the mass measles vaccination campaign of 1992. Our results can help to monitor the effects of vaccination strategies under development. Additionally, our immunogenicity results document the effectiveness of the different vaccine strains used, especially strain L-Zagreb for mumps. We have found no similar comparative studies of these three vaccines in the literature.

Age and sex variables were homogeneously distributed among the three vaccination groups. However, the number of boys and girls vaccinated at each school varied, and this might have introduced a degree of possible systematic bias in the study.

Seroprevalence data obtained before the administration of the triple viral vaccines showed that in the sample of schoolchildren vaccinated against measles at age 9 months, $20.8 \%$ of the subjects had insufficient levels of antibodies for protection. In the sample of schoolchildren without previous vaccination against mumps and rubella, the mean rates of susceptibility were $30.7 \%$ and $44.6 \%$. The vaccines studied showed good immunogenicity for measles, mumps, and rubella with very good levels of seroconversions, and vaccine A (Tresivac) showed a seroconversion rate of $99.5 \%$ for the mumps component, a rate significantly higher than that achieved by the other two triple viral vaccines.

Acknowledgments. We thank the National Immunization Program, the National Health Foundation, and the 
Ministry of Health of Brazil, which supported this research project, and the Fundação de Incentivo à Pesquisa (FIPE) and Grupo de Pesquisa e Pós-
Graduação (GPPP), Hospital de Clínicas de Porto Alegre, for their financial sponsorship. We also thank the three laboratories-Serum Institute of India,
Merck-Sharp \& Dohme, and the Institut Pasteur Mérieux-which provided the vaccines, and Dr. Lenita Simões Krebs for her assistance in preparing the text.

\section{REFERENCES}

1. Henderson DA. Lessons from the eradication campaigns. Vaccine. 1999;17 Suppl 3:S53-5.

2. Ehreth J. The value of vaccination: a global perspective. Vaccine. 2003;21(27-30):4105-17.

3. Oster NV, Harpaz R, Redd SB, Papania MJ. International importation of measles virusUnited States, 1993-2001. J Infect Dis. 2004; 189(Suppl 1):S48-53.

4. de Quadros CA, Izurieta H, Venczel L, Carrasco $P$. Measles eradication in the Americas: progress to date. J Infect Dis. 2004;189(Suppl 1):S227-35.

5. Hersch BS, Tambini G, Nogueira AC, Carrasco $P$, de Quadros CA. Review of regional measles surveillance data in the Americas, 1996-99. Lancet. 2000;355(9219):1943-8.

6. de Quadros CA, Olive JM, Hersh BS, Strassburg MA, Henderson DA, Brandling-Bennett $\mathrm{D}$, et al. Measles elimination in the Americas. Evolving strategies. JAMA. 1996;275(3):224-9.

7. Acharya A, Diaz-Ortega JL, Tambini G, de Quadros C, Arita I. Cost-effectiveness of measles elimination in Latin America and the Caribbean: a prospective analysis. Vaccine. 2002;20(27-28):3332-41.

8. World Health Organization-United Nations Children's Fund. Measles Mortality Reduction and Regional Elimination-Strategic Plan 2001-2005. Available from: www.who.int/ vaccines-documents/. Accessed 26 July 2005.

9. Visser LE, Gonzalez Perez KC, Ramos Tejera J, Berjon Barrientos AC, Vergara Guerrero Y, Martinez Navarro JF. An outbreak of mumps in the Province of Leon Spain 1995-1996. Euro Surveill. 1998;3(2):14-8.

10. Vandermeulen $C$, Roelants $M$, Vermoere $M$, Roseeuw K, Goubau P, Hoppenbrouwers K. Outbreak of mumps in a vaccinated child population: a question of vaccine failure? Vaccine. 2004;22(21-22):2713-6.

11. Robertson SE, Featherstone DA, Gacic-Dobo M, Hersh BS. Rubella and congenital rubella syndrome: global update. Rev Panam Salud Publica. 2003;14(5):306-15.

12. Castillo-Solorzano C, Carrasco P, Tambini G, Ref. S, Brana M, de Quadros CA. New horizons in the control of rubella and prevention of congenital rubella syndrome in the Americas. J Infect Dis. 2003;187(Suppl 1):S146-52.
13. dos Santos BA, Ranieri TS, Bercini M, Schermann MT, Famer S, Mohrdieck R, et al. An evaluation of the adverse reaction potential of three measles-mumps-rubella combination vaccines. Rev Panam Salud Publica. 2002; 12(4):240-6.

14. Markowitz E, Preblud SR, Katz SL. Measles vaccine In: Plotkin SA, Mortimer EA, eds. Vaccines. 2nd ed. Philadelphia: WB Saunders; 1994. Pp. 229-76.

15. World Health Organization. Strategic plan for the elimination of measles in the European Region. Copenhagen: WHO; 1997.

16. Cox MJ, Azevedo RS, Massad E, Fooks AR, Nokes DJ. Measles antibody levels in a vaccinated population in Brazil. Trans R Soc Trop Med Hyg. 1998;92(2):227-30.

17. Cutts FT, Bartoloni A, Guglielmetti P, Gil F, Brown D, Bianchi Bandinelli ML, et al. Prevalence of measles antibody among children under 15 years of age in Santa Cruz, Bolivia: implications for vaccination strategies. Trans R Soc Trop Med Hyg. 1995;89(1):119-22.

18. Mathias RG, Meekison WG, Arcand TA, Schechter MT. The role of secondary vaccine failures in measles outbreaks. Am J Public Health. 1989;79(4):475-8.

19. Anders JF, Jacobson RM, Poland GA, Jacobsen SJ, Wollan PC. Secondary failure rates of measles vaccines: a metaanalysis of published studies. Pediatr Infect Dis J. 1996;15(1):62-6.

20. Cherry JD. Rubella. In: Feigin RD, Cherry JD, eds. Textbook of pediatric infection diseases. 4th ed. Philadelphia: WB Saunders; 1998. Pp. 1922-49.

21. Souza VA, Moraes JC, Sumita LM, Camargo MC, Fink MC, Hidalgo NT, et al. Prevalence of rubella antibodies in a non-immunized urban population, Sao Paulo, Brazil. The Division of Immunization, CVE. Rev Inst Med Trop Sao Paulo. 1994;36(4):373-6.

22. Brazil. Ministério da Saúde, Fundação Nacional de Saúde, Instituto Evandro Chagas. Projeto Pesquisa de Anticorpos na Rubéola. Belem, Brazil; 1990.

23. Morgan-Capner P, Wright J, Miller CL, Miller E. Surveillance of antibody to measles, mumps, and rubella by age. BMJ. 1988; 297(6651): 770-2.
24. Mitchell LA. Sex differences in antibody- and cell-mediated immune response to rubella reimmunization. J Med Microbiol. 1999; 48(12):1075-80.

25. Mitchell LA, Tingle AJ, Decarie D, Shukin R. Identification of rubella virus $\mathrm{T}$-cell epitopes recognized in anamnestic response to RA27/3 vaccine: associations with boost in neutralizing antibody titer. Vaccine. 1999;17(19): 2356-65.

26. Pannuti CS, Moraes JC, Souza VA, Camargo MC, Hidalgo NT. Measles antibody prevalence after mass immunization in Sao Paulo, Brazil. Bull World Health Organ. 1991;69(5): 557-60.

27. Bartoloni A, Cutts FT, Guglielmetti P, Brown D, Bianchi Bandinelli ML, Hurtado H, et al. Response to measles revaccination among Bolivian school-aged children. Trans R Soc Trop Med Hyg. 1997;91(6):716-8.

28. Massad E, Azevedo-Neto RS, Burattini MN, Zanetta DM, Coutinho FA, Yang HM, et al. Assessing the efficacy of a mixed vaccination strategy against rubella in Sao Paulo, Brazil. Int J Epidemiol. 1995;24(4):842-50.

29. Pebody RG, Gay NJ, Hesketh LM, Vyse A, Morgan-Capner P, Brown DW, et al. Immunogenicity of second dose measles-mumpsrubella (MMR) vaccine and implications for surveillance. Vaccine. 2002;20(7-8): 1134-40.

30. World Health Organization. Mumps virus vaccines. Wkly Epidemiol Rec. 2001;45:346-55. Available from: http://www.who.int/docstore/ wer/pdf/2001/wer7645.pdf. Accessed 26 July 2005.

31. Beck M, Welsz-Malecek R, Mesko-Prejac M, Radman V, Juzbasic M, Rajninger-Miholic M, et al. Mumps vaccine L-Zagreb, prepared in chick fibroblasts. I. Production and field trials. J Biol Stand. 1989;17(1):85-90.

Manuscript received on 15 September 2005. Revised version accepted for publication on 16 August 2006. 
RESUMEN Objetivo. Se evaluó la seroprevalencia para sarampión, paperas y rubéola en niños en edad escolar (6-12 años) antes y después de la administración de tres vacunas triples antivirales combinadas.

Prevalencia de anticuerpos contra sarampión, paperas y rubéola en niños en edad escolar antes y después de la vacunación con tres vacunas triples antivirales combinadas diferentes, Rio Grande do Sul, Brasil, 1996

Palabras clave
Métodos. Se colectaron 692 muestras de sangre antes de la vacunación y 636 muestras entre 21 y 30 días después de la vacunación a niños de dos escuelas municipales de Rio Grande do Sul, Brasil, durante 1996. Se investigó la seropositividad de anticuerpos de la clase IgG mediante un ensayo de inmunoadsorción enzimática tipo ELISA (sarampión y paperas con Enzygnost [Behring, Marburgo, Alemania] y rubéola con Rubenostika [Organon Teknica, Boxtel, Países Bajos]). Las vacunas comparadas fueron: a) E-Zagreb, L-Zagreb y Wistar RA 27/3 (Tresivac); b) Moraten, J-Lynn y Wistar RA 27/3 (M-M-R II); y c) Schwarz, Urabe AM-9 y Wistar RA 27/3 (Trimovax). Resultados. Antes de la vacunación, 79,2\% (intervalo de confianza [IC] 95\%: 76,0 a 82,2 ) de las muestras fueron positivas para sarampión, 69,4\% (IC 95\%: 65,8 a 72,8) para paperas y 55,4\% (IC 95\%: 51,6 a 59,2) para rubéola. Después de la vacunación con las vacunas A, B y C, la seropositividad fue de 100\%, 99,5\% y $100 \%$, respectivamente para sarampión; de $99,5 \%, 94,5 \%$ y $92,0 \%$ para paperas; y de $92,6 \%, 92,3 \%$ y $88,6 \%$ para rubéola.

Conclusiones. Alrededor de un quinto $(20,8 \%)$ de los escolares que pudieron haber sido vacunados contra el sarampión a los 9 meses de edad tenían niveles de anticuerpos insuficientes para protegerlos. En la muestra de escolares sin vacunación previa contra paperas y rubéola se encontró una alta proporción de niños susceptibles. Todas las vacunas fueron inmunogénicas, pero la vacuna A produjo una tasa de seroconversión de $99,5 \%$ para el componente de paperas, significativamente mayor que la de las otras dos vacunas $(P<0,01)$.

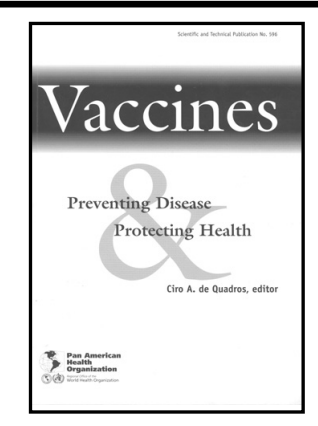

\section{Vaccines: Preventing Disease and Protecting Health IS NOW AVAILABLE IN ELECTRONIC FORMAT}

In this book you will find information about how vaccines have improved the health of the world's populations. The book relates successful efforts to fight disease with vaccines, including the eradication of polio from the Americas, and the potential contribution of new measles vaccine formulations to reducing measles mortality worldwide. It also looks at the challenges posed in using vaccines to cope with emerging and re-emerging diseases, such as HIV/AIDS, and in the fight against bioterrorism.

Electronic Version: 2004, 412p., ISBN 927511596 6, Order code: SP-E 596, Price: US $\$ 40.00$

To access the electronic version, follow these three simple steps:

1. Visit the site: www.ingentaselect.com

2. Select Pan American Health Organization in the Browse by publisher option

3. Select Vaccines: Preventing Disease and Protecting Health

Or go directly to PAHO publications by visiting:

http://www.ingentaselect.com/pubjournals.htm?pb=paho 